\title{
Guidelines of Digitalizing Waste Industry Infrastructure
}

\author{
Komyshova L.N.* \\ Voronezh State Technical University \\ Voronezh, Russia \\ e-mail: mila_kom@mail.ru \\ Serebryakova E.A. \\ Voronezh State Technical University \\ Voronezh, Russia \\ Kryuchkova I.V. \\ Voronezh State Technical University \\ Voronezh, Russia \\ e-mail: irishka-kryuchkova@mail.ru
}

\author{
Belyantseva O.M. \\ Voronezh State Technical University \\ Voronezh, Russia
}

Smorodina E.P.

Voronezh State Technical University, Voronezh, Russia

Gunina M.A.

Voronezh State Technical University

Voronezh, Russia

\begin{abstract}
For many years, environmental legislation has been undergoing changes aimed to alter a waste management system. In this regard, one of the priority areas of the Voronezh region socio-economic development for the period until 2035 in the field of environmental protection and rational nature management is the construction of an inter-municipal ecological waste processing cluster. It aims to solve the environmental problems of the region by increasing the share of recyclable and utilized waste as well as reducing the number of landfills for their disposal. Integrated monitoring of transmitting the region to a new waste management system revealed the major problem of the waste processing industry transformation being a lack of an effective infrastructure for the collection, sorting and disposal of municipal solid waste as well as a lack of a single information resource to support this process. It is possible to increase the effectiveness of the reforms by digitalizing the industry under discussion. This study considers world achievements concerning waste processing industry digitalization, and also it analyzes scientific research on the development of an information component of the waste processing cluster. The study uses the method of comparative analysis of various digitalization factors. As a result of the analysis, the main directions of innovative development of the waste processing industry were identified. The existing digitalization technologies have been analyzed. An innovative infrastructure model of the waste processing industry has been proposed, and the recommendations on the development of the innovative infrastructure of this industry have been formulated.
\end{abstract}

Keywords - innovative infrastructure, waste processing cluster, digitalization, digital technologies

\section{INTRODUCTION}

At present, one of the main environmental problems in the world is the annually increasing volume of waste generation, which significantly exceeds the volume of its processing and disposal, which leads to an increase in the number of landfills.
The need to improve the system of a safe waste management and the elimination of already accumulated environmental damage were the prerequisites for changing environmental legislation in Russia. The key idea of environmental reform is the creation of an effective industry for waste processing and disposal as well as the involvement of the secondary material resources in the economic turnover through the formation of environmentally oriented clusters and ecological parks.

In the previous works devoted to the introduction of a new waste management system and formation of the waste industry infrastructure, we gave a detailed review of the regulatory framework on the basis of which the waste industry is being currently transformed in Russia and in the Voronezh region in particular. Based on these documents, the territory of our region was divided into eight zones combined into a single inter-municipal ecological waste processing cluster [1]. Many regional operators were not ready to fulfill the prescribed functions and refused to perform work. Thus, at the moment only the Voronezh inter-municipal ecological waste processing cluster has begun its operation. As well there arose the need to revise the territorial scheme for waste management in order to reduce the distance of waste delivery to landfills in inter-municipal clusters.

Features and problems of adopting a new waste management system are considered in the scientific works of M.V. Latypova, E.S. Zakharchenko. They came to the conclusion that the ecological safety of the region, as a rule, depends on the degree of development of the infrastructure for the safe waste management.

Works of N.S. Tomilina, T.V. Litvinova are devoted to the innovative infrastructure development in Russia. The features of developing the innovative infrastructure of the industry for processing waste abroad were considered by Maria S. Shiro, A.A. Napalkova, A.E. Nasadyuk. 
As a result of the analysis of scientific research, we came to the conclusion that the efficiency of waste collection and processing can be improved by betterment of the management system through digitalizing the safe waste management infrastructure. This deduction leads to the conclusion concerning the relevance of the topic under discussion.

The aim of our study is to analyze the main directions of the waste industry digitalization, a review of world and domestic achievements in the field of digital technologies for the waste collection and processing with the objective to determine the directions of innovative development of infrastructure facilities of the Voronezh inter-municipal ecological waste processing cluster.

\section{METHODS AND MATERIALS}

Our research goal was achieved by studying the conditions and existing results of the waste industry digitalization. The main research method is the analysis of the legislative and regulatory framework, which became the basis for the development of an intelligent waste management system and scientific materials to ensure high quality and living standards through digital and information technologies.

In accordance with the Government Decision of the state program "Digital Economy of the Russian Federation" and the strategy for the development of the information society in the Russian Federation for the period until 2030, the Ministry of Construction of Russia in 2019 developed and approved the standard "Smart City". The standard provides a list of measures, whose implementation will provide the sustainable social and economic development of the city and the region as a whole due to digitalization of the urban economy and creation of new information services.

The term "Smart City" implies that it is a city without waste. Therefore, one of the main areas of the standard is the development of an intelligent environmental safety system, which includes two basic measures, whose implementation is being provided until 2023 (table 1):

TABLE I. MEASURES ON THE WASTE MANAGEMENT SYSTEM AUTOMATION

\begin{tabular}{|l|l|}
\hline \multicolumn{1}{|c|}{ Basic measures } & \multicolumn{1}{c|}{ Expected impacts } \\
\hline \multirow{2}{*}{\begin{tabular}{l} 
Development and $\begin{array}{l}\text { implementation of an } \\
\text { information system for safe } \\
\text { waste management }\end{array}$ \\
\cline { 2 - 2 }
\end{tabular}} & $\begin{array}{l}\text { Improving the efficiency of the regional } \\
\text { operator in waste collection and removal. }\end{array}$ \\
\cline { 2 - 2 } & $\begin{array}{l}\text { Optimization of the specialized machinery } \\
\text { traffic routes } \\
\text { municipal solid waste collection and } \\
\text { removal }\end{array}$ \\
\cline { 2 - 2 } & $\begin{array}{l}\text { Ability to automatically analyze the costs } \\
\text { of collection, removal and disposal of } \\
\text { waste and tariff setting. }\end{array}$ \\
\hline $\begin{array}{l}\text { Providing control over the } \\
\text { movement and operation of } \\
\text { specialized machinery for } \\
\text { the municipal solid waste } \\
\text { collection and removal }\end{array}$ & $\begin{array}{l}\text { Implementation of online operational } \\
\text { control over the vehicles movement }\end{array}$ \\
\hline
\end{tabular}

Vladimirov D.G., Vorotnikov A.M., Ipatova N.S. and Tarasova B.A. consider that the creation of an intelligent management system for the safe management of waste is the most effective and less costly way to manage and control this process [2]. The industry's information development strategy involves digital presentation of data, its processing and use at each stage of the waste life cycle to make effective management decisions. From the stage of waste generation on down to its disposal, a large number of subjects from different industries having their own waste management schemes come into interaction. Alignment of interests of the subjects from different sides can be achieved with a good regulatory framework, modern innovative technologies for waste collection, sorting and processing as well as information infrastructure.

The following main directions of digital solutions development are distinguished on the world market of waste processing industry:

- production and implementation of a smart garbage collection system "smart containers";

- provision of specialized equipment "smart waste bins" with sensors and software to optimize waste transportation;

- production and implementation of innovative technologies for sorting, processing and disposal of waste;

- development and implementation of information technology.

"Smart containers" are equipped with special sensors enabling to control their filling with sorted garbage. Special marks on containers read out by a vehicle when collecting garbage, thereby confirming its removal.

Digital software for specialized equipment transporting garbage enables to determine the amount of waste in a container, in a car and the waste unloaded at a landfill for disposal or recycling.

The increase in secondary material resources requires the introduction and development of various innovative technologies for the municipal solid waste collection and processing. An overview of some Russian innovative projects addressing the issue of waste processing is presented in table 2 .

The main trends in information technology that can be used in the field of waste management are presented in Table 3 [3].

According to the largest research company Frost \& Sullivan, at the beginning of 2020 the global market for the digital transformation of the waste management industry was approximately $\$ 3.6$ billion. About 50 companies are developing smart technologies for collecting, sorting, processing and transporting waste. Among them, one can distinguish such companies as ZenRobotics, Sadako Technologies, Compology, Trux, Bigbelly. Leaders in the field of specialized software production are Waste Management, Rubicon Global, Winnow Solutions. Innovative technologies are used in the countries of North America and Western Europe most actively. 
TABLE II. INNOVATIVE PROJECTS IN WASTE MANAGEMENT

\begin{tabular}{|c|c|}
\hline Wastetech projects & Project concept \\
\hline $\begin{array}{l}\text { Wasteout is a system for } \\
\text { optimizing and controlling } \\
\text { the export of municipal } \\
\text { solid waste. } \\
\text { Company founder is Rodion } \\
\text { Klyuyev }\end{array}$ & $\begin{array}{l}\text { Development of ultrasonic sensors that } \\
\text { record the fact of filling and emptying a } \\
\text { container. By transmitting data to the online } \\
\text { planning and control system, the algorithms } \\
\text { predict the degree of fullness of the } \\
\text { containers, on the basis of which the } \\
\text { optimal route for the collection and } \\
\text { removal of garbage is calculated. }\end{array}$ \\
\hline $\begin{array}{l}\text { Ubirator is a waste } \\
\text { management service. } \\
\text { The project founders are N. } \\
\text { Nikishin and A. Khatskevich }\end{array}$ & $\begin{array}{l}\text { A single information platform brings } \\
\text { together waste suppliers, carriers and } \\
\text { collection points. It works on the Uber } \\
\text { principle. }\end{array}$ \\
\hline $\begin{array}{l}\text { Fineplastic is plastic } \\
\text { collection and processing } \\
\text { The project founder is } \\
\text { A. Dashiev }\end{array}$ & $\begin{array}{l}\text { The project involves the development of } \\
\text { "smart" containers on a by-order basis or } \\
\text { providing customers with waste containers } \\
\text { already developed by the company as well } \\
\text { as the provision of separate waste } \\
\text { collection services. }\end{array}$ \\
\hline $\begin{array}{l}\text { TukaTuka is a buy and sell } \\
\text { service of recycled } \\
\text { materials. } \\
\text { The project founder is G. } \\
\text { Ponomarev. }\end{array}$ & $\begin{array}{l}\text { An information platform with ads on } \\
\text { buying and selling quality secondary plastic } \\
\text { materials. }\end{array}$ \\
\hline $\begin{array}{l}\text { Binology is the } \\
\text { development of a smart } \\
\text { litter bin SmartCity } \\
\text { The project founder is the } \\
\text { company Netmus, which } \\
\text { supplies equipment for } \\
\text { waste processing. }\end{array}$ & $\begin{array}{l}\text { The "smart" bin SmartCity can be powered } \\
\text { by a solar battery and is equipped with a } \\
\text { system for pressing waste, which reduces } \\
\text { its volume; sensors of a litter bin } \\
\text { completeness, atmospheric pressure and air } \\
\text { temperature. Various waste bin } \\
\text { configurations are provided. }\end{array}$ \\
\hline $\begin{array}{l}\text { Re.actor is a buy and sell } \\
\text { service of all types of liquid } \\
\text { waste. } \\
\text { Founder of the project is } \\
\text { Sibur }\end{array}$ & $\begin{array}{l}\text { Information platform with announcements } \\
\text { of buying and selling waste subjected to } \\
\text { processing, indicating the place, date of } \\
\text { export, quantity and price per unit of waste. }\end{array}$ \\
\hline $\begin{array}{l}\text { Aurora Borealis is safe } \\
\text { waste disposal. } \\
\text { A project founder is A. } \\
\text { Klimov }\end{array}$ & $\begin{array}{l}\text { An innovative thermal waste treatment } \\
\text { plant with minimal air pollution has been } \\
\text { developed. It enables to reach the level of } \\
\text { gas purification up to } 99 \% \text {. }\end{array}$ \\
\hline $\begin{array}{l}\text { "Ecoenergy Laboratory" is } \\
\text { production of waste } \\
\text { processing equipment. }\end{array}$ & $\begin{array}{l}\text { Development of specialized equipment in } \\
\text { the form of separators, which enables } \\
\text { automatic waste sorting. }\end{array}$ \\
\hline
\end{tabular}

TABLE III. MAIN TRENDS IN INFORMATION TECHNOLOGY

\begin{tabular}{|l|l|}
\hline Information Technology & \multicolumn{1}{|c|}{ Information technology characteristics } \\
\hline $\begin{array}{l}\text { PaaS, SaaS) } \\
\text { Big Data }\end{array}$ & $\begin{array}{l}\text { Provide remote access to servers, databases, } \\
\text { storage and applications via Internet } \\
\text { connection. }\end{array}$ \\
\hline Blockchain & $\begin{array}{l}\text { A set of special methods and tools that } \\
\text { enables storing and processing huge amounts } \\
\text { of data aimed to solve specific problems in } \\
\text { any industry. This technology is one of the } \\
\text { most effective analysis tools. }\end{array}$ \\
& $\begin{array}{l}\text { An electronic database consisting of } \\
\text { information blocks interconnected with each } \\
\text { other. Information is stored on users' } \\
\text { computers. Data on all ongoing changes are } \\
\text { available and visible to each participant in } \\
\text { the system. Due to this, all data becomes } \\
\text { transparent, and there is no possibility of } \\
\text { original data loss or falsification. }\end{array}$ \\
\hline Internet of things (IoT) & $\begin{array}{l}\text { The technology includes sensors for various } \\
\text { purposes, meters, weather stations, route } \\
\text { builders, which transmit all the information } \\
\text { to the cloud storage. System users receiving } \\
\text { relevant information can quickly process it. }\end{array}$ \\
\hline
\end{tabular}

As for Russian companies, the leader in the development of digital technologies in the field of waste management is the Kazan company OOO "Atton Group". They have developed electronic territorial schemes for 10 regions of Russia. The model of the territorial scheme contains information on waste management, specifically, how much garbage is transported, where, where from, by what carrier, and with what periodicity as well as information about landfills and unauthorized landfills.

At present, territorial waste management schemes have been developed in 73 out of 85 regions of Russia. In accordance with the law, by the end of 2020, territorial schemes should be converted into electronic form [4]. According to the Atton Group, the main problem is that many regions simply digitized the data that was on paper. And the main functionality of the electronic circuit is the ability to monitor morphology and volumes of generated waste, circuits and waste flows as well as the ability to predict changes in landfill location maps in real time. The main task is to increase the transparency of waste movement throughout their entire life cycle. This can only be achieved through the creation and implementation of end-to-end digital technologies. In this case, each stakeholder will have the opportunity to receive the following information: who generated the waste and in which volumes; who and when collected it; who, how and when processed or disposed it; what secondary material resources can be acquired and where.

In order to improve the environmental situation Atton Group together with the multi-profile block chain company Bitfury Group, began to develop a distributed registry technology in the waste management system based on the blockchain platform. It is planned to equip landfill sites with electronic platforms for measuring weight with integrated photo and video recording. This system is designed to collect and process information about imported garbage and specialized vehicles entering landfills. The new system will eliminate the unjustified increase in the tariff for transportation and disposal of municipal solid waste. The introduction of new technology is planned to begin with the Vladimir region in the second half of 2020 [4].

Representatives of Atton Group believe that the creation of an intelligent waste management system will have a significant impact on the labor market. On the one hand, automation will cause cuts. On the other hand, digitalization will offer new vacancies that require staff development or new specialists training. The lack of an appropriate educational policy can have a negative impact on the formation of the waste processing industry [5].

A round table held in Kazan in April 2018 was devoted to the development of environmental educational resources in the context of digitalization of the safe waste management system. As a result of discussions, the round-table participants came to the conclusion that it is necessary to create a new professional environmental standard "Waste Management Specialist". The labor functions of such a specialist include the possession of design, construction, and environmental management skills based on the use of digital technologies, uniting a large number of different participants [6]. And it was decided at 
Sevastopol State University to create the first Russian department of "Software Engineering of Intelligent Systems", which will train the specialists for implementing the state project "Smart City".

Thus, the educational centers on the basis of higher education institutions included in the waste processing cluster will appropriately and timely train the necessary specialists.

\section{RESULTS}

The implementation of digitization program in the processing and safe waste management industry requires such an infrastructure that will provide new digital services through information systems, computer technology, and digital platforms that provide for the collection, processing, transmission and storage of information. Based on the research conducted by V.M. Volodin and N.A. Nadkina in the field of digitalization of agricultural production, we have formulated and presented the main directions of innovative development of the waste processing industry in Figure 1 [7].

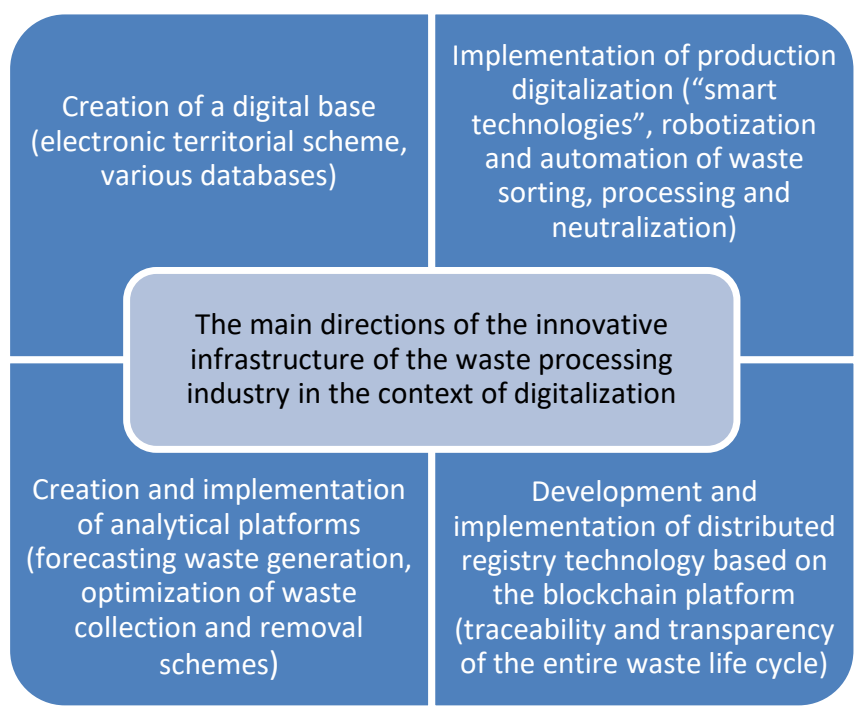

Fig. 1. The main directions of developing the innovative infrastructure of a single inter-municipal ecological waste processing cluster in the context of digitalization

Thus, the improvement of infrastructure in the field of safe waste management involves the introduction of information, digital and research infrastructure, generating a "smart city", which is especially important in the context of clustering. The interconnection of these elements will favour a quick respond to changes in this industry. A model of the innovative infrastructure of the waste processing industry in the context of digitalization is presented in Figure 2

A fully formed infrastructure for the safe waste management will allow the creation of an intelligent urban waste management system, the main elements of which are presented in Figure 3 [2].

The introduction of an intelligent waste management system will ensure high-quality interaction of stakeholders, carry out operational control on the basis of timely received real data and thereby increase the efficiency of management processes.

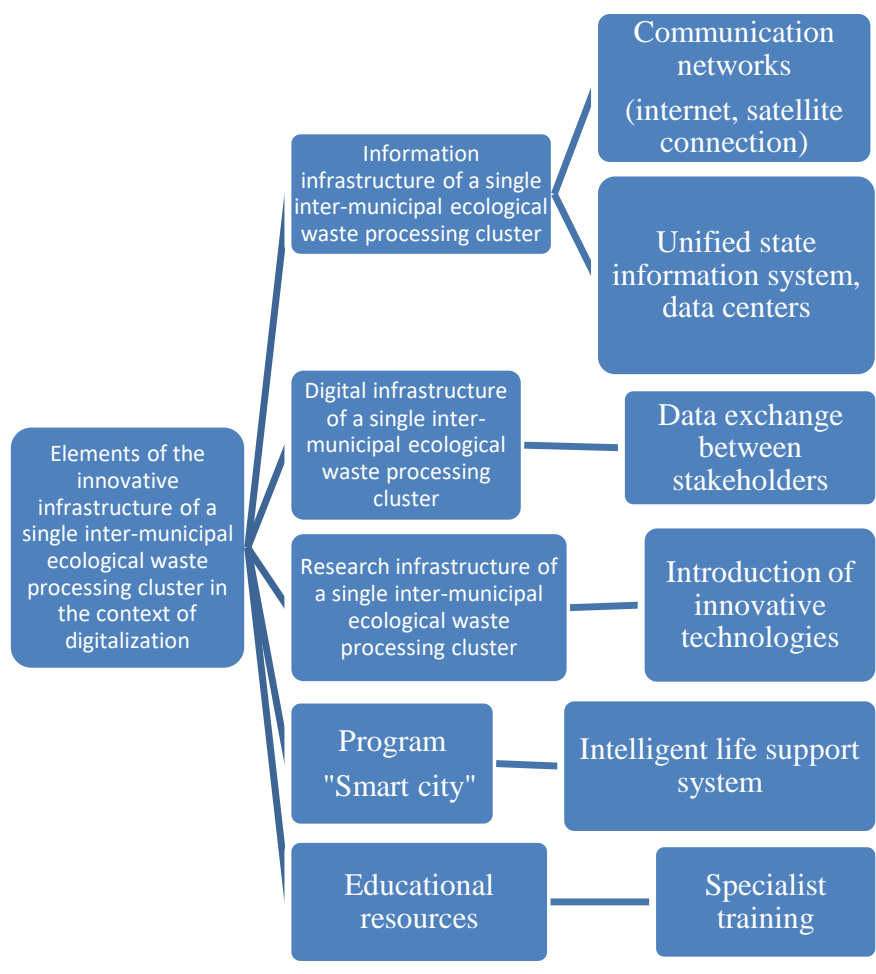

Fig. 2. Model of innovative infrastructure of the waste processing industry in the context of digitalization

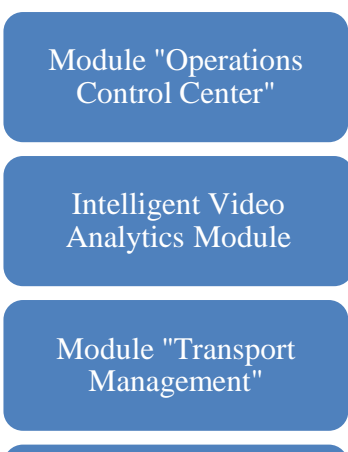

- Processing, analysis and presentation of information in various forms

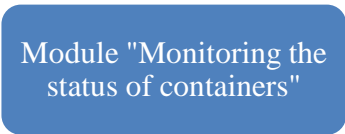

- Control of separate collection of waste and the filling of garbage containers

Module "Environmental monitoring of territories"

\section{- Environmental monitoring in the city and at a single inter-municipal ecological waste processing cluster facility}

Fig. 3. The modular structure of an intelligent waste management system

\section{DISCUSSIONS}

The results of the study enables to conclude that digitalization of a single inter-municipal ecological waste processing cluster infrastructure significantly depends on the development of partnerships between IT companies and companies involved in the field of safe waste management. An increase in the number of joint projects will make it possible to gradually move to a responsible model for the safe waste management and its processing and to timely fulfill the tasks of the Strategy for socio-economic development of the Voronezh region in terms of "waste" [8]. 
Transition to a new waste management system in the context of digitalization requires significant costs. Therefore, it is necessary to consolidate the funds of the regional budget, funds provided by the national project and payments from the population in the form of a tariff. Attracting investments in a single inter-municipal ecological waste processing cluster on the basis of public-private partnerships will significantly accelerate the pace of creating a unified information system, thanks to which many processes will become more understandable and transparent [9].

\section{V.CONCLUSION}

The development of environmental waste processing clusters contributes to the implementation of innovative production and digital technologies, which in turn ensures sustainable social and economic development of the region. At the same time, environmental problems of the territory are solved [10].

Digitalization plays an important role in the formation of the innovation infrastructure of the cluster as it ensures the transparency of economic processes and the coherence of actions between people, business and government authorities [3].

The activity of any cluster involves the collection, analysis and storage of a huge amount of varying information. Therefore, the lack of a unified intelligent management system can slow down the transition to a new system for the safe management of waste.

\section{Acknowledgment}

The authors are grateful to the faculty of the Department of Digital and Industrial Economics of Voronezh State Technical University (VSTU) under the guidance of Professor N.V. Sirotkina, whose scientific works helped to draw attention to the relevance of our chosen topic.

We express special gratitude to the professor of the Department of Digital and Industrial Economics of VSTU S.S. Uvarova for valuable advice when planning a study and recommendations for the design of the article.

\section{References}

[1] E.N. Zhutaeva, E.A. Serebryakova, I.V. Kryuchkova, "Formation of a new waste management system based on a cluster approach in the territory of the Voronezh region", Econ. and Entrepreneurship, vol. 9-4, no. 86, pp. 979-982, 2017.

[2] D.G. Vladimirov, A.M. Vorotnikov, N.S. Ipatova, B.A. Tarasov, "Waste Management "Smart City" using technological intelligent systems", J. of Manag. Studies, Rubric: Econ., organizat. and manag. of enterprises, industries, complexes, vol. 4, no. 9, 2018. Retrieved from: https://naukaru.ru/ru/nauka/article/23582/view

[3] M.S. Shiro, "Structural and functional characteristics of the information and telecommunications components of the innovation cluster", Sci. and Techn. Sheets of SPbSPU, Econ. sci., vol. 11, no. 4, pp. 242-250, 2018. DOI: 10.18721 / JE.11419

[4] K. Sokolova, "Cross-cutting digital technologies begin with the trash", Busin. Electr.Newspaper "Business OnLine", dated 12.16.2019. Retrieved from: https://business-gazeta.ru/article/450177

[5] E. Avdeeva, T. Davydova, N. Skripnikova, L. Kochetova, "Human resource development in the implementation of the concept of "smart cities"', no. 110, p. 10, 2019 [E3S Web Conf., Int. Sci. Conf. SPbWOSCE-2018 "Business Technologies for Sustainable Urban Development”, no. 02139. DOI: 10.1051/e3sconf/201911002139

[6] E.A. Avdeeva, T.E. Davydova, “A new model of labor and employment in the context of the digitalization of the economy", pp. 3-7, 2019 [Actual problems of economic development: Sat. doc. X Int. correspondence sci. and pract. Conf.]. Belgorod: Publ. House of BSTU V.G. Shukhov.

[7] V.M. Volodin, N.A. Nadkina, "Formation of an innovative infrastructure for digitalization of production at industrial enterprises and agribusiness", News of higher educational institutions. Volga region. Econ. sci., vol. 2, no. 8, pp. 3-12, 2018. DOI 10.21685 / 2309-28742018-2-1

[8] The Law of the Voronezh Region dated 20 December 2018, no. 168-OZ "On the Strategy for the Social and Economic Development of the Voronezh Region for the Period until 2035" Retrieved from: https://econom.govvrn.ru/its/strategiya-sotsialno-ekonomicheskogorazvitiya

[9] V.V. Gasilov, M.A. Karpovich, I.V. Kryuchkova, "Model for the implementation of a public-private partnership project in environmental protection", pp. 93-98, January 31, 2014 [Conf. proc. "The International Scientific and Practical Congress of Economists and Lawyers "the genesis of genius". (Geneva, Switzerland).

[10] N.M. Vetrova, A.A. Gaysarova, "Development of ecological and economic management of the region: Ecological clusters of industry", Scientific notes of the Crimean Federal University named after V.I. Vernadsky, Econ. and Manag., vol. 3, iss. 69, no. 2, pp. 18-26, 2017. 